\title{
BSA Involvement Score 0
}

National Cancer Institute

\section{Source}

National Cancer Institute. BSA Involvement Score O. NCI Thesaurus. Code C131035.

No body surface area involved. 